IRSTI 64.35.21

UDC 685.34.73

\title{
RECYCLING OF LEATHER AND SHOE WASTE
}

\author{
${ }^{1} J$. USENBEKOV, ${ }^{1}$ B.KH. SEITOV, ${ }^{1}$ S.K. NURBAY, ${ }^{1}$ I.R. ABENOVA \\ ('«Almaty Technological University» JSC, Almaty, Kazakhstan) \\ E-mail: Zh.usenbekov@mail.ru
}

\begin{abstract}
Waste from the leather and footwear industries is not disposed of at the enterprises, but is taken to landfills, which leads to environmental pollution. Research of waste processing technology in order to reduce their negative impact on the environment is an urgent task. The paper considers the processes of shredding leather and Shoe production waste, technological processes for obtaining secondary raw materials and products from them. For this purpose, an installation has been developed that allows studying the process of grinding waste suitable for further processing in laboratory conditions. Studies were carried out to determine the rational modes of the technological process of grinding waste from these industries. The sequence of processing and the obtained values of the modes are recommended for use in production conditions.
\end{abstract}

Key words: leather and Shoe production Waste, processing process, rational modes, wet processing, heat treatment, grinding, processing of crushed waste.

\section{ТЕРІ ЖӘНЕ АЯҚ КИІМ ӨНДІРІСТЕРІНІН ҚАЛДЫҚТАРЫН ҚАЙТА ӨНДЕУ}

\author{
${ }^{1}$ Ж. УСЕНБЕКОВ, ${ }^{1}$ Б.Х. СЕИТОВ, ${ }^{1}$ С.К. НУРБАЙ, ${ }^{1}$ И.Р. АБЕНОВА \\ ('«Алматы технологиялық университеті» АК, Алматы, Қазақстан) \\ E-mail: Zh.usenbekov@mail.ru
}

Былгары және аяқ киім өндірісінің қалдықтары әлі толық қолданыс таппады және көп жсавдайда оларды сыртқа шыzарып тастайды, бұл жсавдай қоршаван ортаның ластануына әкеледі. Қалдықтардың қоршаган ортага жазымсыз әсерін азайту үшін оларды қайта өңдеу технологиясын зерттеп, қолданысқа еңгізу өзекті мәселе. Сондықтан, бұл мақалада былzары жсәне аяқ киім өндірісінің қалдықтарын ұсақтау үрдістері, олардан шикізат пен өнім алудың технологиялық үрдістері талқыланады. Осы мақсатта зертханалық жсагдайда қалдықтарды одан әрі өңдеуге жарамды ұсақтау үрдісін зерттеуге мүмкіндік беретін қондыргы жасалды. Өндіріс қалдықтарын ұнтақтаудың технологиялық үрдісінің ұтымды режсимдерін анықтау үшін зерттеулер жүргізілді. Өңдеу реті және оның режимдерінің мәндерін өндіріс жсагдайында қолдануга ұсынылды.

Негізгі сөздер: тері және аяқ киім өндірістерінің қалдықтары, қайта өңдеу үрдістері, тиімді режимдер, ылғалмен өндеу, жылумен өндеу, ұнтақтау, ұнтақталған қалдықтарды кайта өңдеу.

\section{ПЕРЕРАБОТКА ОТХОДОВ КОЖЕВЕННОГО И ОБУВНОГО ПРОИЗВОДСТВ}

\author{
${ }^{\prime}$ Ж. УСЕНБЕКОВ, ${ }^{l}$ Б.Х. СЕИТОВ, ${ }^{1}$ C.К. НУРБАЙ, ${ }^{1}$ И.Р. АБЕНОВА
}

( ${ }^{1} \mathrm{AO}$ «Алматинский технологический университет», Алматы, Казахстан)

E-mail: Zh.usenbekov@mail.ru

Отходы кожевенного и обувного производства не утилизируются на предприятиях, а вывозятся на свалки, что ведет к загрязнению окружающей среды. Исследования технологии переработки отходов с целью снижения негативных воздействий их на окружающую среду 
является актуальной задачей. В работе рассмотрены процессы измельчения отходов кожевенного и обувного производства, технологические процессы получения вторичного сырья и продукта из них. Для этой цели разработана установка, позволяющая изучить в лабороторных условиях процесс измельчения отходов, пригодных для дальнейчей переработки. Проведены исследования по определению рациональных режимов технологического процесса измельчения отходов данных производств. Последовательность обработки и полученные значения режимов рекомендованы к использованию в производственных условиях.

Ключевые слова: отходы кожевенного и обувного производств, процесс переработки, рациональные режимы, влажная обработка, тепловая обработка, измельчение, переработка измельченных отходов.

Introduction. Currently, the waste of leather and shoe production is destroyed by burial or incineration at special landfills or landfills. This method of destruction of production waste cause significant harm to the environment and ecology. The appearance of this problem arose due to the lack of an effective technological approach to the processing and disposal of leather waste. In advanced, developed countries, the role of waste recycling in these industries is significantly increased.

Kazakhstan has a large amount of waste products that are not sold at light industry enterprises. The bulk of the waste, unfortunately, does not find rational use and they are sent to landfills and pollute the environment. In this regard, work on the processing and use of light industry waste as a high-grade raw material is an urgent problem.

Purpose of the research. The issue of recycling or processing waste generated in the leather and shoe industries is constantly being considered. But this problem has not yet been completely resolved. The most widely used material in shoe manufacturing is chrome tanned leather. Its amount is about $80-90 \%$ of the total volume of skin [1]. When using this product in shoe production, a lot of waste is generated. The main source of waste occurs when cutting the upper shoe blanks. The volume of such waste is $20-30 \%$ of the total area of skin consumed. About fifty percent of the residues are burnt, and the remaining fifty are buried without reuse. This is harmful to the environment and human health. Recycling and disposal of waste has become a new direction in the light industry, which can significantly reduce the environmental burden from the leather industry and deliver a significant amount of useful products to the market [2].

As a result of the study, the following areas of reuse of shoe production wastes can be distinguished: separation of leather wastes into fibers and obtaining new material; harvesting feed and fertilizers in agriculture; the use of drugs in production and others [3].

Various methods of grinding with subsequent de-fibration of tannery waste have been developed [4]. There is a known method in which leather waste is moistened, the moistened waste is mechanically processed and then it is de-fibered.

Among them, the recycling of waste and the production of usable artificial materials is important for shoe production. In this regard, this paper discusses the processing of collagencontaining waste in the manufacture of footwear, including technological processes for producing artificial material.

Object and methods of research. The object of research is the technological process of processing collagen-containing wastes from leather and shoe production to obtain artificial material.

For this purpose, a more efficient method for obtaining crushed powdery material from waste is proposed. The method involves soaking in an aqueous medium with the addition of alkali metal salt, drying and grinding in a dry state. At the same time, the process of waste processing in the work was considered on the following operations: separation of waste into small pieces; weakening of molecular bonds in leather waste using moisture and alkali; rapid heating of soaked waste and rapid removal of moisture from them and giving new properties to waste (brittleness); mechanical grinding of dried waste suitable for producing artificial material.

Results and their discussion. The work performed at the initial stage of waste disposal consists in relaxing the molecular bond of the skin residues of collagen fibers in a humid environment. This operation was carried out in a laboratory using a hydrolyzing agent in a domestic autoclave (Fig. 1). In an autoclave at high temperature and pressure, leather waste is wetted and brought to a moisture content of about $85 \%$. 


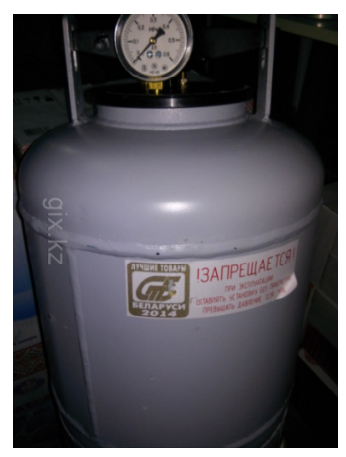

Figure 1 - Appearance of a domestic autoclave

Wetted waste is dried in a drying oven at a temperature of 160-180 oC (in a household oven) for 30-50 minutes.

As a result of heating, the waste turns into a brittle material. Dried wastes are further

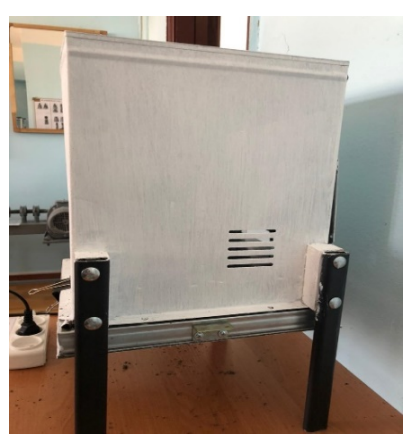

Figure 2 - The appearance of the crushing plant (mills)

Since a household autoclave and a working chamber are produced by the factory, the principle of their operation is given in the technical documentation.

In this regard, we consider the work of a grinder manufactured in laboratory conditions. The installation has 1 knife rotating, running,

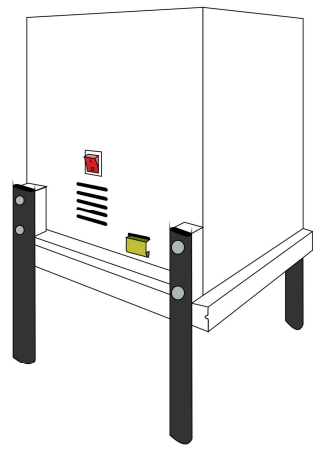

$a$ crushed, skin fibers are separated separately. Waste crushing is carried out on a specially manufactured laboratory unit. Figure 2 shows the appearance of the installation, and Figure 3 shows the working tools of this installation.

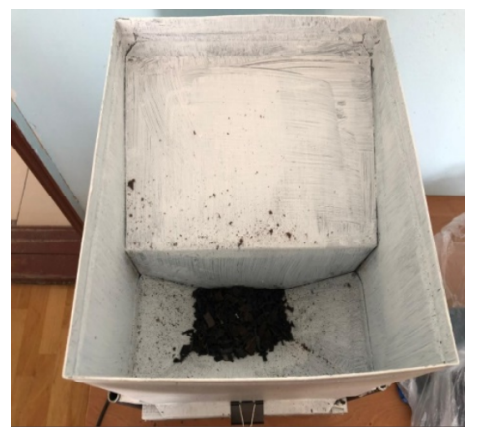

impact (Fig. 4). The knife is attached to the motor shaft. Dried tanning residues are crushed with a rotating knife, as well as a blow between the knife with fixed multi-cutting holes and on the rack, sheathed with external 3 cuts. The milled waste is sieved through a sieve and collected in a container 4 (Fig. 4).

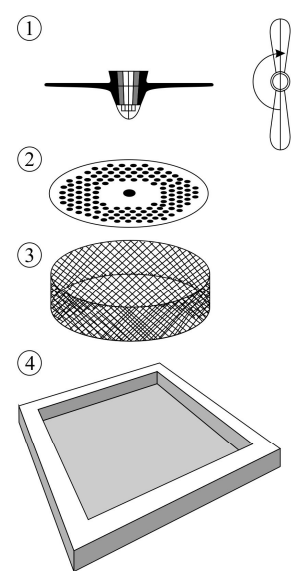

$b$

Figure 3 - Installation tool (a-appearance, b-tool) 1-knife, 2-fixed disk with holes, 3-sieve, 4-pallet 


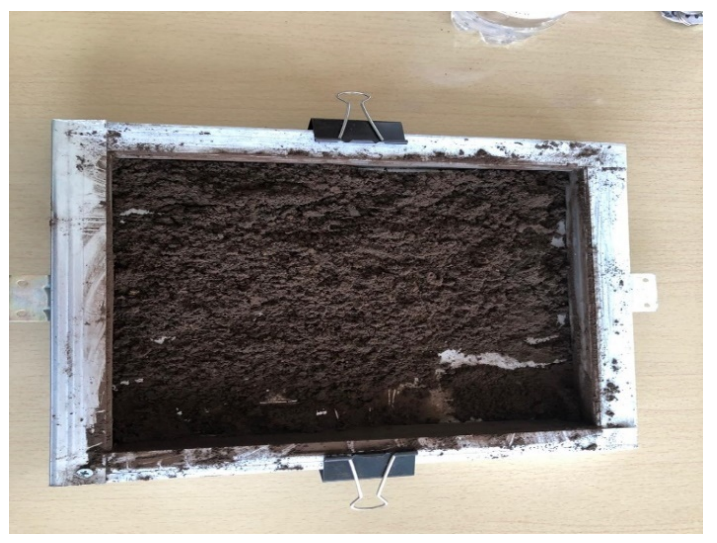

Figure 4 - Crushed waste

When examining the grinding process, it is important to choose the rotational speed of the rotor knife of the mill depending on the type of waste. At high knife speeds, powders can burn. In this regard, during the study, a rational knife speed was determined for the remains of shoe blanks and haberdashery leather waste. A good result of grinding leather waste from the upper of the shoe is at a knife rotation speed of 1750 $2000 \mathrm{rpm}$, and $1000-1500 \mathrm{rpm}$ is enough to grind leather waste from haberdashery products.

The resulting powders were used as a filler necessary for the manufacture of artificial materials similar to some leather. For example, leather dust (powder) was used as a filler for rubber-based mixtures. At the same time, a quarter of the total mass of the mixture was made up of leather dust, which had a significant impact on the properties of the mixture: resistance to aggressive media, abrasion resistance, and elongation improved.

For a comparative analysis of the properties of the obtained sample of artificial material in comparison with natural leather, the abrasion resistance was determined according to GOST R 50714-94 [6]. The test results are shown in table 1.

As can be seen from table 1, the abrasion coefficient of the obtained sample is higher than that of the natural one. It is known that the higher the coefficient of abrasion, the better and longer the material will last. This means that the resulting sample is more wear-resistant.

Table 1-results of testing samples for abrasion

\begin{tabular}{|c|c|c|c|}
\hline Sample & $\begin{array}{c}\text { Weight up to } \\
\text { attrition, } \mathrm{g}\end{array}$ & Weight after abrasion, $\mathrm{g}$ & $\begin{array}{c}\text { Abrasion resistance, } \\
\mathrm{m} \mathrm{kg} / \mathrm{j}\end{array}$ \\
\hline Genuine leather & 8,318 & 8,093 & 38,717 \\
\hline Experimental sample & 9,393 & 9,104 & 49,747 \\
\hline
\end{tabular}

Also, crushed leather waste was used as fillers to produce non-woven fabric. At the same time, glue webs were used as a binding element. This adhesive method of producing the web is the most productive, since it actually requires a minimum range of raw materials-fiber and the necessary equipment for the production of heatbonded web, where the main element is a furnace. There is no need to use expensive materials that are harmful to the health of the worker. In this treatment, samples were obtained that imitate natural suede.

Crushed waste was used to increase the strength, as a reinforcing component in the manufacture of decorative polymer tiles based on epoxy resins (Fig. 5, a)

Samples were obtained (Fig. 5) by including powders in plastic and elastomer in various quantities. Their properties were tested and rational compositions of mixtures were determined. 

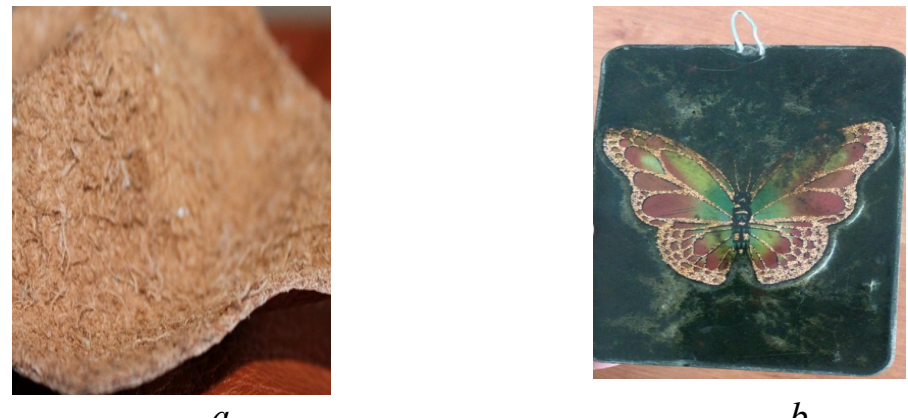

$b$

Figure 5 - Samples obtained from powdered leather waste (a-a decorative product in which crushed leather fibers are used as a reinforcing component, b-a sample of artificial material)

Conclusion. In this work, the trend and rational mode of obtaining new collagencomposite materials were determined by studying in the laboratory the methods of processing leather and Shoe production waste, obtaining ready-made fiber-porous materials.

Laboratory testing of elastomers filled with crushed leather waste allowed to reduce their cost and give them specific properties. The fibrous filler made it possible to improve the bonding ability and increase the physical characteristics of the material

The results obtained are expected to be used as a basis for industrial development in the future.

\section{REFERENCES}

1. Abeeva D. J., Blieva M. V. New directions for the use of waste leather production. http://www. scienceforum.ru $/ 2014 / 665 / 2873$

2. Shestov A.V. Technologies for processing leather production waste.// Innovative economy: prospects for development and improvement, No. 8 (18), 2016. - PP. 179-184.

3. Shestov A.V. [Text]: Monograph. / Technologies for producing Shoe leather using NNTP processing and special products based on it for the petrochemical complex. - Kazan: Publishing house of KAZAN state technical University, 2016. - 267 p.

4. Method of processing leather waste into leather powder: Pat. 2041264 of the Russian Federation, From 14 To 13/00/ V. V. Samonin, Yu. V. Bogdanov; applicant "ALT" LLP, no. 93010246/12; application 01.03.1993; publ. 09.08.1995. URL: HTTP://ru-patent.info/20/40-44/2041264.html.

5. GOST R 50714-94. Artificial leather. Methods for determining the abrasion and adhesion of the coating.

ӘОЖ 664.69

FTAXP 65.33 .41

\title{
МАКАРОН ӨНІМДЕРІНІН САПАЛЫК КӨРСЕТКІШТЕРІНЕ ҚОСУЙЛІ КАЛАҚАЙ ҰНТАҒЫНЫН ӘСЕРІ
}

\author{
Т.Б. АХЛАН ${ }^{1}$, Г.Е. ЖУМАЛИЕВА², Б.Ж. МУЛДАБЕКОВА
}

('Қазақ ұлттық аграрлық университеті, ${ }^{2}$ «Қазақ қайта өндеу және тағам өнеркәсіптері ғылымизерттеу институты» ЖШС, ${ }^{3}$ «Алматы технологиялық университеті» АҚ, Алматы қ., Қазақстан) E-mail: togzhan.akhlan@gmail.com

Бұл мақалада зертханалық жаздайда бидай ұны құрамына жүгері ұны және Urtica dioca l. ұнтагы қолданылып, заманауи технологиялық рецептурава сай дайындалган өнімнің физикалық жжне химиялық сипатамалары зерттелді. Ғылыми мәліметтерге сәйкес қосүйлі қалақай жсапырақтарының химиялық құрамын С, К, В дәрумендері, пантенон қышқылы, құмырсқа қышқылы, каротин, қальций құрайды. Сол себепті, макарон өнімдерінің құрамына қосүйлі қалақай ұнын қосу, жүрек пен өкпенің жұмысын бір қалыпты ұстауда, бауыр және өт жолдарының созылмалы дерттерін алдын алуда ықпалын тигізеді. Зерттеу нәтижесіне сай 20\% жүгері ұны, сондай-ақ 2\% қосүйлі қалақай ұнтаzы қосылzан макарон өнімдерінің 